\title{
Overview and Performance of the SMMEs Sector in South Africa
}

\section{Tendai Chimucheka}

\author{
Department of Business Management, University of Fort Hare \\ Alice, P.B. X1314, Eastern Cape, 5700, South Africa. \\ E-mail: tenchims@gmail.com; Tel: 0027 (0) 406022272
}

Doi:10.5901/mjss.2013.v4n14p783

\begin{abstract}
This paper provides an overview of Small, Micro and Medium Enterprises (SMMEs) in South Africa. The paper also investigates the contribution and importance of the SMME sector in South Africa, challenges faced by SMMEs as well as issues pertaining to SMME performance. Resource requirements of SMMEs are also discussed. Information was gathered though an extensive literature review.
\end{abstract}

Keywords: Performance, SMME, Resources, South Africa

\section{Introduction}

SMMEs in South Africa continue to contribute positively to the economy of the nation. According to South Africa Info (2005), SMMEs in South Africa have come to play an increasingly important role in the South African economy and development, especially now that large enterprises have restructured and down-sized. The government has therefore targeted the SMME sector as an economic empowerment vehicle for previously disadvantaged people.

The objectives of this paper include to:

- Provide an overview of SMMEs in South Africa,

- Discuss the contribution and importance of the SMMEs sector in South Africa

- Investigate the challenges faced by SMMEs and their resource needs

- Discuss SMMEs performance and performance measures

\section{Overview of SMMEs in South Africa}

Post apartheid South Africa faces socio-economic problems that need urgent attention, similar to those in other developing countries. The challenges include a very high unemployment rate, skills shortages, high illiteracy rate, an ever escalating crime rate and rural poverty. Chalera (2007:9) observes that these challenges are more prevalent in rural communities. SMMEs should be empowered to be able to help solve some of these challenges in South Africa.

South African SMMEs are diversified and operate in different industries, including retailing, wholesaling, tourism, mining, farming, manufacturing, construction and service. Similar to SMMEs in other developing countries, SMMEs in South Africa also face challenges that affect their growth and survival.

When the substantial contribution of SMMEs is considered in South Africa, it is imperative that they should receive much attention. The South African government however does acknowledge the importance of a strong and vibrant SMME sector. This is demonstrated in its commitment to the promotion and the support for SMMEs that aim at increasing the number of new enterprises and creating an enabling environment to ensure their survival and growth. The government hopes to achieve such goals through the National Small Business Act of 1996.

The National Small Business Act 102 of 1996 provides the regulatory and support framework for SMMEs. This defines an SMME as a separate and distinct business entity, including cooperative enterprises and non-governmental organisations, managed by one owner or more, which includes its branches or subsidiaries, if any, and is predominantly carried out in any sector or subsector of the economy.

The guidelines appearing in the National Small Business Act 102 of 1996 ascertain that SMMEs can be defined in both qualitative and quantitative terms. Nieman and Pretorius (2004:3) mention the qualitative criteria, which also relate to the ownership structure that can be used to define SMMEs. The mentioned qualitative criteria stipulate that SMMEs 
should be separate and distinct business entities, cannot be part of a group of companies, must include subsidiaries and branches when determining its size, should be managed by its owners, and can be a natural person in the form of a sole trader or partnership. It can also be a legal person such as a close corporation or a company.

The Act also classifies business ventures into very small, micro, medium and small sizes using quantitative criteria (Nieman\& Pretorius, 2004:4). Total full-time paid employees, total annual turnover and the gross asset value are the quantitative criteria that are set in terms of the standard classification by industry in the Act.

Cronje et al., (2001:492) identified the characteristics observable among SMMEs. The characteristics are that:

- SMMEs are generally more labour intensive than larger businesses;

- on average, SMMEs generate more job opportunities per unit of invested capital;

- they are an instrument for utilising the talents, energy and entrepreneurship of individuals who cannot reach their full potential in larger organisations;

- SMMEs often flourish by rendering services to a small or restricted market which larger businesses do not find attractive;

- they are also breeding grounds for entrepreneurial talent and the testing ground for new industries;

- SMMEs contribute to the competitiveness of the economy; and

- SMMEs create social stability, cause less damage to the physical environment than large factories, stimulate personal savings, increase prosperity in rural areas and enhance the population's general level of economic participation.

SMMEs are also characterised by their small size. In pricing, they are usually followers, whilst ingenuity, creativity and devotion are typical characteristics of SMMEs (Cronje et al., 2001:492). Because of their size, SMMEs are most suited for rural communities where the markets are too small to justify the existence of large businesses (Dzansi, 2004: 33).

Agupusi (2007:1) reports that since 1994, South Africa has been promoting small business as an engine for economic growth and socio-economic integration. More recently, due to the growth of unemployment, there has been a renewed focus on the promotion of SMMEs. This is from both the government and the private sector. They are not simply focusing on SMMEs as an engine for growth, but more importantly as the key to job creation and poverty reduction, especially among historically disadvantaged groups.

Chalera (2007:1) states that the South African government established institutions and programmes designed to improve the access of the SMME sector to critical resources. The major resources include finance, infrastructure, training and counselling, information, markets and technology.

A call for efforts to strengthen the SMMEs' associations and chambers as well as efforts to improve the legislative and regulatory environment for the small, medium and micro business sector is being heard.

SMMEs are expected to function as a driving force, both in South Africa's social and economic transition. This will however be possible if they are supported by the supply side measures, targeting enterprise's constraints.

Kesper (2000) suggests that only the few, more dynamic SMMEs in South Africa show a potential to contribute to rapid employment creation, while survivalist activities constitute the vast majority of the South African SMME economy. He also argued that South African SMMEs grow in numbers, not in size.

\section{Contribution and Importance of SMMEs}

It can be argued that most entrepreneurial activity takes place in SMMEs. Nieman and Nieuwenhuizen (2009:3), confirm that SMMEs form $97 \%$ of all businesses in South Africa, generating 35\% of the Gross Domestic Product.

Nieman and Nieuwenhuizen (2009:276) are of the view that SMME development was identified by the new South African government as a priority in creating jobs to solve the high unemployment rate in the country. Nieman and Nieuwenhuizen (2009:276) makes it clear that the promotion of entrepreneurship and small business development was seen by the new South African government in 1994 as a way of addressing the following generic developmental goals in the country, which are:

\subsection{Job or employment creation}

With the formal sector to absorb the high and growing number of job seekers in the country, there has been an increased attention paid to entrepreneurship, mainly because of the potential that it possesses in contributing to significant economic growth and employment creation. 


\subsection{Poverty alleviation}

Poverty occurs throughout the whole world. It is only the level of poverty that varies. Research indicates that poverty is significantly higher in developing countries than in developed countries. The government of South Africa HAS identified SMMEs as a key to poverty alleviation. SMMEs combine the resources of societies efficiently to produce goods and services for the society in which they operate (Du Toitet al., 2009:49).

\subsection{Equity and participation}

The South African government's strategy has been focusing primarily on the development of SMMEs in previously disadvantaged communities. Previously disadvantaged communities have been described as those sections of the population that had been disadvantaged by apartheid and segregationist development policies before 1994. It is SMMEs that commonly provide economic and employment opportunities to the general members of the community. Income inequality between population groups in South Africa is still believed to be high and SMMEs are expected to help reduce this problem.

\subsection{Social stability}

The government recognises the importance of developing a strong SMME sector. It is internationally accepted and acknowledged that the SMME sector is an essential factor in promoting and achieving economic growth and development, as well as in the widespread creation of wealth and employment (Nieman \& Nieuwenhuizen, 2009:276).

\subsection{Economic growth and development}

SMMEs are often the vehicle by which the people who earn the lowest income in the South African society gain access to economic opportunities. Central to the growth of the economy, is the development of a vibrant SMME sector, which development experts agree, is the key to resolving many societal challenges, including job creation (Entrepreneur SA, 2005:3).

Estimates in the year 2009 show that SMMEs contribute more than 35\% of South Africa's Gross Domestic Product and employ close to three quarters of the nation's employed population. Comparative studies of large and small businesses carried out in other countries, confirm that SMMEs generally employ more labour per unit of capital, and require less capital per unit of output, than large businesses (Luiz, 2002:16).

Antonites (2003:9) points out that the SMME sector provides employment, pays taxes and can be included in the government statistics and in labour market information analyses. SMMEs also act as training grounds by offering apprenticeships for the youth.

SMMEs can also contribute largely to the sustainable development of South Africa in areas of economic growth, employment generation, poverty alleviation and community development. They also enable people to meet their basic needs and thus survive. Through job creation, SMMEs are able to help raise the standard of living for South African citizens.

\subsection{Contribution of SMMEs to sustainable development}

The World Business Council for Sustainable Development (2004) advises that improving the performance of SMMEs is one of the key drivers of sustainable development through contribution to economic growth, poverty alleviation, employment generation, crime reduction and community development.

\subsection{Contribution of SMMEs to economic growth}

The World Business Council for Sustainable Development (2004) points out that the key to poverty alleviation is economic growth that is inclusive and reaches the majority of the people. Wealth creation, one of the core competencies of the private sector, plays a vital role in the poverty alleviation process. Thus, it should be attempted to improve the performance and sustainability of local entrepreneurs and SMMEs because they play a major role in helping to achieve sustainable growth. According to the National Small Business Act (2003), SMMEs are expected to be an important 
vehicle to address the challenges of job creation, sustainable economic growth, equitable distribution of income and the overall stimulation of economic development. Small firms are also a crucial source of innovation in the development of new products, services and technologies. The Accelerated and Shared Growth Initiative South Africa (ASGISA) indicates that a growth rate of $5 \%$ on the average between 2004 and 2014 is needed to achieve the social objective of the government and it is expected that SMMEs could contribute significantly to the expected growth rate.

\subsection{Contribution of SMMEs to employment}

Du Toitet al., (2009:50) noted that SMMEs are able to provide jobs needed by the growing population. They argued that SMMEs create jobs whereas large corporations are shedding off or retrenching.

Kesper, (2001:172) agrees that SMMEs are seen as a vehicle to address the problem of high unemployment levels in South Africa, since they have a high labour absorptive capacity. It is known that SMMEs employ a significant number of South Africans and that they contribute $43 \%$ of the total value of salaries and wages paid in South Africa (Nieman\&Nieuwenhuizen, 2009:3). According to Nieman and Nieuwenhuizen (2009:3), SMMEs employ 55\% of all formal private sector employees in South Africa. Year 2009 estimates show that a staggering 74\% of South Africans active in the economy are employed in SMMEs (The Business Place, 2009:1). This shows that SMMEs play a major role in reducing the problem of high unemployment rates that is faced in many of the African countries.

\subsection{Other contributions of SMMEs}

Besides the already mentioned issues of job creation, economic growth and development, and an increase in GDP, other potential benefits directly accruing to local governments because of the activities of the SMME sector, include the empowerment of local citizens, competition among the developing businesses in tandem with the positive benefits of quality by the suppliers as well as a broader base and choice for the consumer. It also includes a reduction in crime rates, since instead of being idle, citizens are productively engaged (Yanta, 2001:44).

\subsubsection{Competition}

SMMEs compete against large producers and improve the nature of the competitive environment leading to quality products and services in the economy (Du Toitet al., 2009:50). They also compete against one another which is of benefit to customers in terms of quality and price.

\subsubsection{Aiding big firms}

Some functions can be performed more efficiently and effectively by SMMEs than larger firms. This therefore means that SMMEs can contribute to the success of large firms. It is thus possible that SMMEs can perform the distribution and supply function for large firms (Du Toitet al., 2009:50). SMMEs, such as wholesale and retail outlets, perform a valuable service for big firms by distributing its products to customers. They can also function as suppliers to, and sub-contractors for large firms. Where large firms agree to a long term relationship with SMMEs, the latter can supply a specified level of quality goods, offer lower prices, thereby generating cost-saving ideas.

\section{Challenges Faced by SMMEs in South Africa}

Although the SMME sector in South Africa has received much attention from the government, they still face challenges. Nieman and Nieuwenhuizen (2009:35) identified some challenges that are faced by SMMEs in South Africa. The challenges include lack of training and education, limited access to financial resources, inaccessibility to markets, lack of support structures, inaccessibility to appropriate technology and lack of access to other resources like human resources. The challenges are discussed in the sections that follow.

\subsection{Lack of training and education}

In South Africa, lack of education is seen as one of the most significant barriers to entrepreneurial activity (Nieman\&Nieuwenhuizen, 2009:31). They also noted that education is positively related to entrepreneurial activity. 
Lack of management skills by SMME owners and managers can be attributed to lack of education and training. Education and training help develop management competencies which are necessary for the success of the enterprise. Hellriegel, Jackson, Slocum, Staude, Amos, Klopper, Louw and Oosthuizen (2008:98), defines managerial competencies as sets of knowledge, skills, behaviours and attitudes that can contribute to personal effectiveness. Management competencies are very crucial for the survival and also for the growth of a business venture. Herrington and Wood (2003) point out that in South Africa, it is lack of education and training that has reduced management capacity in SMMEs. Lack of education and training is one of the reasons why there is a very high failure rate of SMMEs (especially the newly established) and low level of entrepreneurial creation.

\subsection{Limited access to financial resources}

All businesses require finances to start trading and also to fund growth. Fatoki and Garwe (2010:731) provide evidence that lack of financial resources is the second most reported contributor to failure of SMMEs, after education and training in South Africa. Foxcroft, Wood, Kew, Herrington and Segal, (2002), shows that $75 \%$ of applications for bank loans by SMMEs are often rejected in South Africa. FinMark (2006) found that only $2 \%$ of new SMMEs in South Africa are able to access finances. SMMEs often find it difficult to access bank finances, mainly because they lack collateral security, the required bank deposit or a credit record. Poor presentation of business plans is also another reason for failure to access bank finances by SMMEs in South Africa.

\subsection{Inaccessibility of markets}

In order to survive and to achieve success, SMME owners and managers need to understand the dynamics of competition in their industry and develop skills and also competencies that will give them a competitive advantage. To understand the market dynamics, operators of SMMEs need to scan and interpret environmental changes, mainly the extent of current and future competition. This will help them to maintain their firm's viability, as well as performance.

The extent of competition and potential competition affects the market potential and growth opportunities of SMMEs. Although the intensity of competition among firms varies widely across industries (David, 2007:86). Failure of some SMMEs to access markets, can be attributed to industry competition, which is determined by what was explained by Michael Porter as the five competitive forces (Du Toit et al., 2009:101).

According to Porter, the nature of competitiveness in a given industry can be viewed as a composite of the five forces (David, 2007:87). Firms or organisations in any industry are directly affected by at least five competitive forces (Hellrigiel, 2008:98). These five competitive forces are rivalry among competitors, threats of new entrants, threats of substitute commodities, customers and suppliers bargaining power. These are also known as the Porter's five forces.

The Porter's five forces model illustrate the competitive forces, thus the sources of competition in any industry. Porter's five forces model is illustrated in figure 1.

Figure 1: Competitive Forces Model

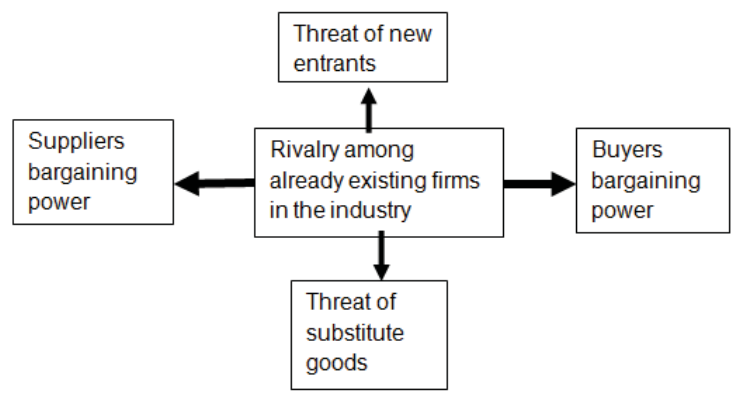

Source: Adapted from Hellrigiel et al., (2008:98)

The sources of competition appearing in figure 1 are discussed in the sections that follow. 


\subsubsection{Rivalry among competitors}

Figure 1 illustrates that rivals or competitors are a force faced by almost every business today. Rivalry among competing firms is usually the most powerful of the five mentioned forces (David, 2007:88). David (2007:88) noted that the intensity of rivalry among competing firms tends to increase as the number of competitors increases, as competitors become more equal, as the demand of industry's commodities declines and as price cutting becomes common. Rivalry among competitors can also increase when customers can easily switch brands, when exit barriers are high and when the fixed costs are high.

Competitors are arguably the most important element of the micro-environment when it is contemplated on from a strategic viewpoint. Rivalry among competitors produces strategies like price cutting, advertising promotions, enhanced customer services and improvements in service or product quality (Hellrigiel et al., 2008:98). Competitors often use these strategies to improve their relative industry or market positions or to respond to others' actions.

As rivalry intensifies, industry profits decline and the industry becomes unattractive (David, 2007:88). SMMEs usually find it difficult to fight competition with well established larger businesses. Larger businesses cut prices as a calculated strategy to remove other businesses from the industry.

\subsubsection{Threats of new entrants}

The threat of increased competition in an industry depends on how easy new firms can compete with already existing ones (McGee, Thomas \& Wilson, 2005:150). In industries where there are no barriers to entry, competition will usually be severe. David (2007:88) mentioned that despite the barriers to entry, new firms can enter industries with high quality products, lower prices and market resources. Large and existing firms usually take advantage of barriers to entry in the industry and block new SMMEs from competing. It is important to note that whenever a new firm enters a particular market or industry, the intensity of competition will increase (David, 2007:88).

\subsubsection{Threats of substitute commodities}

All competitors produce substitute commodities (Hellrigiel et al., 2008:99). The introduction of substitute products in the market by another firm can affect the demand of already existing commodities that serve the same purpose. With the extent of competition today, new products are always introduced into the market.

\subsubsection{Customers' bargaining power}

Customers always try to force prices down, obtain more and higher quality products, and increase competition among sellers (McGee et al., 2005:151). Customers' bargaining power is usually higher when there are many suppliers and fewer buyers.

\subsubsection{Suppliers' bargaining power}

The bargaining power of suppliers control the extent to which they can raise prices above their costs (make profits), or at least reduce the quality of commodities they provide before losing customers (Hellrigiel et al., 2008:99; McGee et al., 2005:151)

The combined force of all these five forces can affect the long term profitability of the business and calls for the owners and management to carefully monitor and diagnose each one of them, as well as their combined effect before making decisions. Van Aardtet al., (2008:55) explain that a mistake that an entrepreneur should never make, is to assume that there is no competitor for a product or service that he or she offers. It is argued that the analysis and understanding of competitors is essential for the development of strategies to fight competition.

\subsection{Lack of support structures}

Most SMME owners and managers believe that they do not get enough support from the government. This may be as a result of lack of information on the available organisations that are established and available to assist them. Most SMMEs in South Africa are not aware of government efforts that are in place to assist them (Maas \& Herrington, 2006). 


\subsection{Inaccessibility of appropriate technology}

Investment in technology and keeping up with information technology is becoming increasingly important to everyone and to all businesses today. Technology plays a very crucial role in the development of businesses. It helps a business to maximise business opportunities and is perceived to be important if a business is to improve on its sales.

It is very important to note that the use of technology involves costs, because of the fact that computer hardware needs to be bought and software will need to be installed. It is beyond doubt that SMMEs without access to finance will find it difficult to access modern technology.

\subsection{Lack of access to other resources such as human resources}

For SMMEs to perform well and to sustain growth, they need to access a pool of qualified, skilled and motivated employees. Considering the difficulties in accessing finance faced by SMMEs, it is difficult and expensive for them to hire skilled labour. Fatoki and Garwe (2010:732) highlight that labour can only be hired at a cost and within the confines of labour regulations, such as the Employment and Minimum Wage Regulations. The quality of infrastructure can also affect the growth prospects of SMMEs. This is a challenge in most developing countries, and South Africa is no exception. It is shown that many developing countries still suffer from deplorable state of infrastructure such as telecommunication, electricity and transportation.

It is thus shown that challenges faced by SMMEs, can have a negative effect on their performance. Performance of SMMEs is discussed in the following section.

\section{Performance of SMMEs}

The performance of SMMEs is of interest to all countries (Olutunla\&Obamuyi, 2008:195). This is mainly because of the critical role played by these businesses in the economic development of any country. The performance of an organisation or business enterprise relates to the efficiency and effectiveness with which it carries out the tasks in the process of providing products and services (Naude, 2007:3).

Barreira (2004:26) admits that there is no consensus on appropriate measures of SMME performance, and prior research had focused on variables for which information was easy to gather. It has also been argued that growth is a more accurate and easily accessible performance indicator than any other accounting measures and hence superior to indicators of financial performance (Barreira, 2004: 26).

SMME performance is indicated by changes in profits, growth in sales and also employment (Olutunla\&Obamuyi, 2008:198). Olutunla and Obamuyi (2008:198) are of the view that improved SMME performance ensures higher profits, higher growth in sales and employment and wealth maximisation of the owners.

Barreira (2004:26) points out that performance is multidimensional in nature and that it is advantageous to integrate different dimensions of performance in empirical studies. In Barreira's view (2004:26), it is possible to regard financial performance and growth as different aspects of performance, each revealing important and unique information. Taken as a unit of meaning, growth and financial performance give a richer description of the actual performance of the firm than each does separately (Barreira, 2004:27), but each receives attention as a separate unit in the sections that follow.

\subsection{Growth}

In the culture of a business, growth is 'written' as the main characteristic of success (Nieman\&Nieuwenhuizen, 2009:275). It is growth that brings the promise of expansion, greater profitability, new enterprises, increase in personnel and the power to attract more highly developed people or create general increase in resources. There are different definitions of business growth and also various ways of measuring it (Fatoki \&Garwe, 2010:731). Fatoki and Garwe (2010:731) highlighted that business growth is typically measured and defined using relative or absolute changes in assets, productivity, profits, profit margins, employment and sales.

Barreira (2004:27) points out that it is accepted that four indicators of growth can be utilised to measure SMME performance. These indicators are sales growth, employment growth, sales growth compared to competitors and market value growth compared to competitors, which receive attention below. 


\subsubsection{Sales growth}

The growth process can be driven by increased demand for SMMEs' commodities. It may also be very difficult for growth in other dimensions to occur without increasing sales. According to Barreira (2004:29), it is arguable that SMMEs can increase their sales without employing more staff or acquiring more resources and outsourcing can increase sales without increasing the employment level or the amount of resources.

Sales growth reflects both short-term and long-term changes in the business enterprise. It is also easy to obtain sales figures and changes in sales volumes. Sales growth is considered the most common performance measure by most entrepreneurs (Barreira, 2004:29). According to Fatoki and Garwe (2010:731), sales data is usually readily available and SMME operators attach high value to sales as one of the indicators of SMME performance.

\subsubsection{Employment growth}

There has been significant interest in the creation of new employment opportunities in South Africa through the development of the SMME sector and also entrepreneurship. Barreira (2004:27) is of the opinion that in the process of rationalisation, it may be possible to replace employees with capital investments because SMMEs are expected to grow and in the process, employ more people. Employee satisfaction and owner satisfaction are also indicators of success (Van Scheers, 2011:5050).

\subsubsection{Comparison of firms}

When assessing performance of SMMEs, comparisons of firms in the same industry and market can help reveal important additional information. Such measures or comparisons can give information on whether SMMEs simply conform to contemporary market trends or whether they show growth patterns that deviate substantially from their industry in general (Barreira, 2004:28).

\subsubsection{Market value growth compared to competitors}

A growing customer base is a sure sign that an SMME is effectively reaching target markets (Van Scheers, 2011:5050). Barreira (2004:29) argues that the market value captures the real value of the firm better than other measures (accounting measures) like net worth and assets. To calculate market value, one needs to divide gross profits by current year sales (to get the gross profit margin). This is a better performance measure, mainly because it does not consider the size of an enterprise.

\subsection{SMME growth as a defining feature}

Growth is a defining feature of an entrepreneurial business. It refers to an increase in a specific parameter during a specific term or time period (Nieman\&Nieuwenhuizen, 2009:278). Growth must be an objective and a strategy for the venture, and it needs to be managed. Nieman and Nieuwenhuizen (2009:278) support the view that growth and performance are generally seen as substitutes for each other. It is a growing firm that is usually considered to be successful and performing well.

\subsection{Characteristics of growing firms}

Nieman and Nieuwenhuizen (2009:278) identified market domination, differentiation, product leadership, flexibility, innovation, orientation towards the future, export activity and related growth as characteristics of growing SMMEs, which are:

- Market domination occurs in niche markets and is measured in terms of their relative market share in the niche market. The ability to dominate markets is one of the main factors that can separate firms that are performing well from those that are not. Successful firms appear to have clearly demarcated market segments that they dominate.

- Differentiation makes firms different and unique from their competitors. This can be in the form of products, distribution or even geography. Ventures that are performing well will always want to be different (or they want 
their products to be different from those of competitors) in the market so that they can easily be recognised by customers.

- According to Nieman and Nieuwenhuizen (2009:279), successful firms and most growing firms are product oriented. They emphasise on quality, as well as branding and value for customers. Growing and successful firms are also characterised by superior performance and a competitive edge that is gained through the introduction of new products and customer service (Nieman\&Nieuwenhuizen, 2009:279). This can be described as product leadership.

- Flexibility refers to the speed and ability to change direction to gain advantage from new opportunities and also to counter threats. Growing firms should be able to change their position in the market and/or their competitive strategy so as to meet the demands of their customers.

- Innovation can be described as doing things differently and better. This is common in growing firms as they continue to seek new and cost effective ways of doing work. Growing firms are also inclined to invest in their future. Investing in the future can include spending resources on marketing, research and development and also capacity building. Growing firms engage in export activities. They do this in order to increase their market size, to increase sales and also to compete globally. Nieman and Pretorius (2004:6) noted that growing firms thrive on innovation. Innovation can be in the form of technology, a new product or a new way of production.

\subsection{Success factors of growth}

The critical success factors for growth as identified by Vinturella (1999:248) include market intelligence, strategic leadership, clarity of purpose, internal infrastructure and strategic planning. The success factors highlighted are briefly discussed in the next sections.

- Market intelligence refers to the ability of SMMEs to perceive and adapt to changes in the marketplace.

- Strategic leadership is the ability to provide clear direction, to delegate, to make decisions and to make longterm plans.

- Clarity of purpose and direction refers to a detailed vision of the business in the future.

- Internal infrastructure includes the ability to support the business's strategies through its internal operations and firm's structures.

- Strategic planning are specific action steps to achieve the firm's long-term goals.

Now that measures or indicators of growth have been discussed, it is also important to outline and discuss measures of financial performance. These are discussed in the following section.

\subsection{Financial measures of performance}

Brewer (2010:18) illustrates that financial performance measurement is about measuring what is happening inside a business by making use of financial information. Financial information used for financial performance measurement can be sourced by means of financial statements and various ratio analyses (Brewer, 2010:18).

According to Olutunla and Obamuyi (2008:198), the use of profitability to measure performance is in line with the assumptions of profit maximisation and utility maximisation. These assumptions are the cornerstones of many economic theories. Van Scheers (2011:5050) admits that profitability is the first aspect taken into consideration when measuring the success of SMMEs.

Olutunla and Obamuyi (2008:198) argue that for profit maximising firms, a strategy to maintain a high level of profitability requires that the firms must produce quality products that can easily be sold to achieve more revenue, especially through effective and efficient marketing strategies.

To achieve the full potential of sales, the product life cycle needs to be considered and the entrepreneurs must maximise the profitability during the growth stage (Olutunla and Obamuyi, 2008:199)

Brewer (2010:61) highlighted financial measures that can be used to measure SMME business activities. The activities are measured by means of accounting include profitability, creditors, stock control, business goals achieved and business sustainability.

It is also important to look critically at the growth of SMMEs. Entrepreneurial ventures set growth as an objective. The following section discusses growth as an objective of SMMEs. 


\section{Growth as an Objective of SMMEs}

Growth is a function of the vision and foresight of entrepreneurs and is also a defining feature of entrepreneurship (Rwigema\& Venter, 2004:436). It is the potential for growth that distinguishes and entrepreneurial venture from an ordinary small business (Nieman\& Pretorius, 2004:31; Nieman\&Nieuwenhuizen, 2009:277). The lack of an entrepreneurial mindset, which constantly seeks growth and innovation, might subconsciously be the major barrier to growth experienced by many SMMEs (Nieman\&Nieuwenhuizen, 2009:276). The need to grow a business can be attributed to the entrepreneurs' need for achievement, power or/ and personal wealth (Nieman\&Nieuwenhuizen, 2009:276). Nieman and Pretorius (2004:31) highlight that it is important to consider resources and risk when planning to grow a business.

According to Nieman and Nieuwenhuizen (2009:277) and Nieman and Pretorius (2004:31), it is important that SMMEs develop a strategy (long term plan) and objectives for achieving growth. Strategies can be focusing on external growth, internal growth or a combination of the two. When setting growth targets, one needs to confirm that the expansion strategy is in line with the capabilities of the firm. This means that growth targets need to take into account the resources that the SMME is able to attract (Nieman\&Nieuwenhuizen, 2009:277; Nieman\& Pretorius, 2004:31).

Growth can be defined in terms of increased sales, increased income or any other quantifiable goal (Nieman\& Pretorius, 2004:31). Nieman and Nieuwenhuizen (2009:277) advise that each action plan must clearly stipulate the resources that will be required to achieve certain goals. The resources include assets, people and capital. Capital may be the main source of growth but is not useful in itself. It must be converted into productive assets (Nieman\& Pretorius, 2004:31). Growth requires proper planning, organisation, direction and control activities. It needs to be managed carefully.

\section{The Process of Growth}

Rwigema and Venter (2004:437) describe growth as a dynamic process with an impact on every function of the business. Nieman and Nieuwenhuizen (2009:280) and Wickham (in Rwigema and Venter, 2004:437) identified four growth perspectives or types namely, financial, strategic, structural and organisational growth. These types of growth are dependent on each other, hence an entrepreneur cannot view growth from one dimensional perspective. An entrepreneur has to consider these perspectives when planning for growth (Nieman\&Nieuwenhuizen, 2009:280; Rwigema\& Venter, 2004:437). Nieman and Nieuwenhuizen (2009:280) advise that failure to attend to one, while favouring another, could result in failure or a managerial crisis. Figure 2 shows the dynamics of growth, as well as how the types of growth relate to each other.

Figure 2: Dynamics of growth

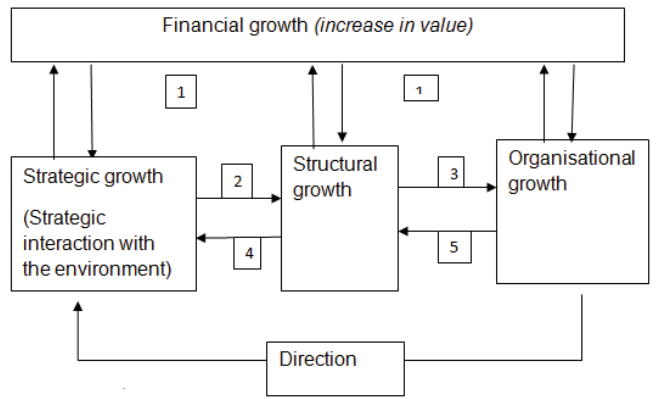

Key: 1: Resources performance; 2: Asset accumulation; 3: Use of assets; 4: Executes; 5: Supports.

Source: Adapted from Nieman\&Nieuwenhuizen, 2009:280

Figure 2 illustrates the different perspectives of growth. These perspectives are briefly discussed below.

\subsection{Financial growth}

This relates to the development of the venture as a commercial entity. Nieman and Nieuwenhuizen (2009:280) agree that 
quantitative measures are generally used as norms to determine growth. Financial growth measures the additional value that will have been created by the business venture. Financial growth is considered as a very important measurement of performance or success of a business. It is financial measurements that stakeholders of a business use to assess the performance of a business.

Rwigema and Venter (2004:438) mentioned that all businesses must grow in terms of assets, level of investment, turnover, necessary cost and also profitability. Ways in which financial growth can be expressed, include an increase in turnover or sales, increases in profits, increase in total sales, increase in return on investment and an increase in any other performance measure. It is financial growth that ultimately affect (give rise to) the economic value of the business (Rwigema\& Venter, 2004:438).

\subsection{Strategic growth}

This refers to changes in which a business interacts with its environment (Rwigema\& Venter, 2004:437). It is concerned with the way in which the enterprise develops capabilities to exploit opportunities in the marketplace. Nieman and Nieuwenhuizen (2009:281) stress the need for firms to adapt and change their strategies as they develop and grow. Strategic growth can take the form of a firm entering new markets, wielding more influence, and facing new different constraints (Rwigema\& Venter, 2004:437).

\subsection{Structural growth}

Structural growth relates to the changes in the way the venture organises its internal systems, managerial roles and reporting procedures, communication ways and also their resource control systems.

Rwigema and Venter (2004:438) are of the view that growth can be represented by enhanced systems' capacity and there is a need for the entrepreneur to continuously revise the systems of the business, including the organisational hierarchy.

\subsection{Organisational growth}

Organisational growth relates to the changes that take place in the organisation's processes, culture and attitudes as it grows and develops. This includes changes in the entrepreneur's role and leadership style as the business grows. Rwigema and Venter (2004:438) reveal that organisational growth refers to the improvement in processes, learning, knowledge and beliefs in the organisation.

\section{Resource Requirements of SMMEs}

Mutezo (2005:6) noted that SMMEs require support if they are to grow and survive. Resources include anything that a business owner or operator need and use to pursue a business opportunity. They can be defined as inputs that the business combines to create the outputs that it delivers to customers (Du Toitet al., 2009:53). Resources can be money that is invested in the business, the people who contribute their efforts, knowledge and skills and also the physical assets. Nieman and Nieuwenhuizen (2009:126); Rwigema and Venter (2004:185), Co, Groenewald, Van Zyl, Visser, Train and Emanuel (2006:157), Du Toitet al., (2009:53) and Van Aardtet al., (2008:56) identified resources that are needed in a business. These resources can be classified in four broad categories, namely human resources, information resources, physical resources and financial resources and are discussed below.

\subsection{Human resources}

These include all people and their efforts, skills, knowledge and insights that they contribute to the overall performance of the business venture. Human resources include all the personnel who are indirectly and directly involved in the manufacturing, rendering a service or selling commodities (Van Aardtet al., 2008:56).

To improve their human resource efforts, entrepreneurs also need to provide training and education to staff. There is also a need to motivate employees so as to encourage high performance. This is supported by Rwigema and Venter (2004:56) who noted that human capital grows out of education and training, innovation, emotional intelligence, wisdom and other skills. 


\subsection{Financial resources}

Any resource that take the form of, or that can easily be converted into cash can be termed a financial resource (Van Aardtet al., 2008:56). Financial resources are very important in any business and to any business owner or operator. It is financial resources that are used to acquire other resources in a business (Rwigema\& Venter, 2004:185; Van Aardtet al., 2008:56).

Entrepreneurs need to determine the nature of financial resource needs and investigate proper means to obtain the necessary financial resources. Different sources of financial resources exist, but they can simply be classified into two broad categories, which are debt and equity. These two broad categories have their own advantages and disadvantages that the entrepreneurs need to be aware of in order to deal with these issues.

These financial resources can be in the form of start-up capital, long-term or short-term loans, trade credit, start-up grants and investments by owners or shareholders (Van Aardtet al., 2008:7). Financial resources need to be carefully managed, because poorly managed cash flow has been identified as one of the main causes of SMME failure.

\subsection{Physical resources}

Van Aardt et al., (2008:56) refer to physical resources as operating resources. They include physical assets such as buildings and equipment. Physical resources also include raw materials that could be used to create the products and services of a business. General supplies used in the operation of the business can also be considered as physical resources. In short, physical resources refer to the facilities which allow people to do their jobs (Van Aardtet al., 2008:56).

\subsection{Information resources}

Nieman and Nieuwenhuizen (2009:128) are of the view that without information, entrepreneurs will not be able to make appropriate decisions. Information sources can be internal (within the business) or external (outside the business). Both internal and external sources are very important to entrepreneurs for they will allow them to develop well informed strategies to fight competition as well as to improve performance of their ventures.

Information resources also include computer technology, the Internet and e-mail as well as patents (Van Aardt et al., 2008:56). These can be a source of competitive advantage for they are unique to the organisation (Rwigema \& Venter, 2004:186).

\section{Conclusion and Recommendations}

This paper focused on the overview and performance of SMMEs in South Africa. Attention was given to growth and financial measures of performance. Performance can be measured in both financial and non-financial terms. Resource requirements for SMMEs were discussed and it was found that for SMME owners to be successful there are certain resources that they need. A lack of these resources can either lead to underperformance or total failure of these business establishments. It is recommended that the government should intervene in assisting some of the SMME owners and managers, but in a more sustainable way that will not promote a spirit of dependence.

The challenges faced by SMMEs in South Africa were also discussed. It is clear that SMME owners and managers, if empowered with entrepreneurial skills and knowledge through entrepreneurship education and training, they will be able to find solutions for the challenges they face. It is recommended that entrepreneurship education and training programmes be made accessible to potential entrepreneurs. The role of SMMEs in the development of South Africa cannot be overlooked for SMMEs contribute significantly in employment creation as well as to the GDP of this country.

\section{References}

Agupusi, P. 2007. Small Business Development and Poverty Alleviation in Alexandra, South Africa. School of Development Studies, University of East Anglia, Norwich, UK.

Antonites, A.J. 2003. An Action Learning Approach to Entrepreneurial activity, innovation and opportunity finding. PhD. University of Pretoria. [Online]. Available: http://74.125.77.132/search/q=cache.DIZnExwD91tmw.j.ftp/ftp.zew.de/pub [Accessed: 10 July 2009].

Barreira, J.C.D. 2004. The Influence of Business Knowledge and work experience as antecedents to entrepreneurial success. Thesis. University of Pretoria. 
Brewer, J.P. 2010. Sustainability of South African FMCG SMME retail businesses in Cape Peninsula. Cape Peninsula University of Technology.

Chalera, C. S. 2007. An Impact analysis of South Africa's national strategy for the development and promotion of SMMEs. University of Pretoria. (Online). Available: http://upetd.up.ac.za/thesis/available/etd-05022007-102936 [Accessed 10 June 2010].

Cronje, G.J., Du Toit, G.S. And Motlatla, M.D.C. 2001. Introduction to Business Management. Cape Town: Oxford University Press, Southern Africa.

David, F.R. 2009. Strategic Management: Concepts and cases, $11^{\text {th }}$ Edition. Pearson.

Du Toit, G.S., Erasmus, B.J. And Strydom, J.W. 2009. Introduction to Business Management. $7^{\text {th }}$ Edition. Oxford, Southern Africa.

Dzansi, D.Y. 2004. Social Responsibility of SMMEs in Rural Communities. University of Pretoria.

Fatoki, O. And Garwe, D. 2010. Obstacles to the growth of new SMEs in South Africa: A principal Component analysis approach. African Journal of Business Management, 4(5):729-738.

Fatoki, O. And Odeyemi, A. 2010. Which New Small and Medium Enterprises in South Africa Have Access to Bank Credit. International Journal of Business and Management, 5(10):128-136.

Finmark Trust. 2006. Fin Scope Small Business Survey Report. (Online). Available: http://www.finmarktrust.org.za [ Accessed 3 April 2010].

Foxcroft, M., Wood, W., Kew, K., Herrington, M. And Segal, N. 2002. Global Entrepreneurship Monitor South African Report [Online]. Available: http://www.gbs.nct.ac.za/gbswebb/userfiles/gemsouthafrica2000pdf [Accessed: 10 May, 2009].

Government Gazette Of The Republic Of South Africa. 2003. National Small Business Amendment Act [On-line] Available: http//www.info.gov.za/gazette/acts/2003/a26-03/pdf [Accessed 11 August 2011].

Hellriegel, D., Jackson, S. E., Slocum, J., Staude, G., Amos, T., Klopper, H.P., Louw, L. And Oosthuizen, T. 2008. Management. $2^{\text {nd }}$ South Africa Edition. Oxford University Press. Oxford.

Herrington, M. And Wood, E. 2003. Global Entrepreneurship Monitor, South African Report [online] Available: http://www.gbs.nct.ac.za/gbswebb/userfiles/gemsouthafrica2000pdf. [Accessed 10.05.2010].

Herrington, M., Kew, J. And Kew, P. 2009. Global Entrepreneurship Monitor, South African report. [Online]. Available: http://www.gbs.nct.ac.za/gbswebb/userfiles/gemsouthafrica2000pdf [Accessed 15 October 2009].

Kesper, A. 2000. Failing or not aiming to grow? Manufacturing SMMEs and their contribution to employment growth in South Africa. Paper presented at the 200 TIPS Forum, September, Johannesburg.

Kesper, A. 2000. Making a living in the city: Small and success of Small Enterprises in the Johannesburg Inner City: Paper presented at the Urban Futures Conference, 10-17 July, Johannesburg.

Kesper, A. 2000. Manufacturing SMMEs in the in the Vaal Triangle-Survey results. Report prepared for the office of the Industrial and Policy Research, May, Johannesburg.

Luiz, J. 2002. Small Business Development Entrepreneurship \& Expanding the Business Sector in a Developing Economy: The case of South Africa. The Journal of Applied Business Research, 18(2).

Maas, G. And Herrington, M. 2006. Global Entrepreneurship Monitor South African Executive Report (Online). Available: http://www.gbs.nct.ac.za/gbswebb/userfiles/gemsouthafrica2000pdf Accessed: 10 May 2011].

Mcgee, J., Thomas, H. And Wilson, D. 2005. Strategy: Analysis and Practice. London: McGraw Hill.

McMullan, W.E. And Gillin, L.M. 2001. Entrepreneurship education in the nineties revised. In Brockhauus R, Hills G and Welsch H. (EDS) Entrepreneurship education. A global view. Aldershot. Ashgate.

Mutezo, A.T. 2005. Obstacles in the access to SMME finance: an empirical perspective on Tshwane. Unpublished Thesis. University of South Africa.

Naude, D. 2007. The degree of organizational performance measurement in SMES. A focus on ICT enterprises. Unpublished Dissertation. UNISA.

Nieman, G. And Neuwenhuizen, C. 2009. Entrepreneurship: A South African Perspective. Pretoria: Van Schaik.

Nieman, G. And Pretorius, M. 2004. Managing growth. A guide for entrepreneurs. Cape Town: Juta and Co. Ltd.

Rwigema, H. And Venter, R. 2004. Advanced Entrepreneurship. Oxford University Press: Southern Africa.

Segal, G. Borgia, D. And Schoenfeld, J. 2005. The motivation to become an entrepreneur. International Journal of Entrepreneurship Behaviour and Research. 1(11):42-57

Thomas, A.B. 2004. Research Skills for Management Studies. London \& New York: Routledge.

Van Aardt, I., Van Aardt, C., Bezuidenhout, S. And Mumba, M. 2008. Entrepreneurship and New Venture Management. $3^{\text {rd }}$ Edition. Oxford University Press: Southern Africa.

Van Scheers, L. 2011. SMEs' marketing skills challenges in South Africa. African Journal of Business Management, 5(13):5048-5056.

Vinturella, J.B. 1999. The entrepreneur's field book. Prentice Hall, Upper Saddle River.

Wickham, P.A. 1998. Strategic Entrepreneurship: A Decision Making Approach to New Venture Creation and Management. Pitman, London

Wickham, P.A. 2001. Strategic Entrepreneurship. A decision-making approach to new venture creation and management. $2^{\text {nd }}$ Edition. United Kingdom. Prentice Hall.

Yanta, Z. 2001. Development monitor- Local government supporting or stunting SMME growth? Indicator South Africa, 18(1): 44-48. 